\title{
MORATORIUM (INZHAR AD-DAIN) \\ DALAM TINJAUAN HUKUM ISLAM
}

\author{
Haryono \\ Dosen Tetap Prodi Perbankan Syariah \\ Sekolah Tinggi Agama Islam (STAI) Al Hidayah Bogor
}

\begin{abstract}
Abstrak
Sebelum dunia keuangan kontemporer mengaplikasikan konsep moratorium dalam pembayaran utang, Islam sudah jauh hari mengenalkan konsep ini kepada umatnya. Di dalam Al-Qur'an sendiri terdapat ayat-ayat tentang moratorium yang menjadi dasar apliksi konsep moratorium. Bukan sekedar itu, banyak pula hadis-hadis yang menerangkan bahkan memerinci bagaimana konsep moratorium yang profesional, adil dan tidak merugikan kedua belah pihak. Seiring berjalannya waktu konsep moratorium semakin populer dalam dunia keungan global. Bahkan bukan sekedar menjadi solusi kemacetan keuangan, namun sengaja digunakan sebagai cara untuk mendapatkan keuntungan. Banyak perusahaan, instansi bahkan negara yang memberlakukan moratorium untuk mendapatkan bunga tambahan dari keterlambatan pembayaran utang. Padahal konsep dasar moratorium adalah akad sosial (tabarru') yang memang tidak boleh digunakan untuk mengambil keuntungan. Di dalam tulisan ini dikupas bagaimana hukum Islam memandang kasus moratorium yang dijadikan sebagai sarana mendapatkan keuntungan atau manfaat sekaligus bagaimana hukum penalti dalam kasus moratorium. Begitu juga syarat-syarat dibolehkan dan dilarangnya moratorium serta sanksi yang akan diterima bagi mereka yang sengaja tidak melunasi hutang setelah moratorium baik di dunia dan akhirat. Jadi dengan menelaah tulisan ini kita bisa mendalami hakikat moratorium di dalam Islam, tinjauan ayat dan hadis tentang moratorium, syarat-syarat dibolehkan dan dilarang moratorium, hukum tambahan manfaat dan penalti dalam moratorium serta sanksi yang didapat bagi siapa saja yang tidak melunasi pembayaran utang.
\end{abstract}

Kata kunci: moratorium, (inzhar ad-dain), penalti, gharamah maliyah, utangpiutang. 


\begin{abstract}
Before the contemporary finance world applied the concept of a moratorium on debt repayment, Islam had long ago introduced this concept to its people. In the Qur'an itself, there are verses about the moratorium which became the basis of apliksi moratorium concept. Not only that, there are also many traditions that explain even detail how the concept of a moratorium that is professional, fair and not harms both parties. Over time the concept of the moratorium is increasingly popular in the world of global finance. Not even just a solution to financial congestion, but deliberately used as a way to gain profit. Many companies, even state agencies that impose a moratorium on obtaining additional interest from late payment of debt. Though the basic concept of a moratorium is a social contract (tabarru') which it should not be used to take advantage. In this paper, we discuss how the Islamic law sees the moratorium case as a means of obtaining profit or benefit as well as how the law of penalty in case of the moratorium. So are the conditions allowed and prohibited moratorium and sanctions will be accepted for those who intentionally do not pay off debt after the moratorium both in the world and the hereafter. So by examining this article, we can explore the nature of the moratorium in Islam, the review of verses and traditions about the moratorium, the conditions allowed and prohibited moratorium, additional law benefits and penalties in the moratorium and sanctions obtained for anyone who does not pay off debt payments.
\end{abstract}

Keyword: moratorium, (inzhar ad-dain), penalty, gharamah maliyah, debt payments.

\section{A. PENDAHULUAN}

Hari ini banyak sekali penawaran yang menggiurkan kepada masyarakat agar mereka terlilit hutang tanpa sadar. Jika zaman dahulu para pengusaha dan perorangan yang hendak membutuhkan modal harus mendatangi bank. Hari realita tersebut telah mulai banyak berbeda. Zaman ini justru kita saksikan pihak lembaga keuanganlah yang agresif keliling ke masyarakat untuk menawarkan berbagai macam pinjaman. Selain itu, pinjaman yang 
ditawarkanpun sangat menggiurkan karena bisa cair hanya dalam beberapa saat saja. Di samping itu, kondisi ekonomi yang semakin sulit menjadikan masyarakat semakin mudah terlilit hutang. Lebih ironis lagi banyak masyarakat yang berhutang untuk bergaya hidup mewah demi mendapatkan status social di tengah masyarakat.

Tidak dipungkiri bahwa salah satu problematika kehidupan yang banyak melanda mayoritas manusia adalah berhutang. Hutang memang salah satu resiko berat bagi seseorang atau perusahaan dalam menjalani eksistensi kehidupan. Di samping menimbulkan ketidaknyamanan dalam pikiran, berhutang seringkali menjadikan pelakunya stress dan depresi. Bagaimana tidak, seseorang yang berhutang seringkali merasa rendah diri saat bertemu di hadapan orang yang dihutanginya. Tidak jarang disebabkan hutang pelakunya berbuat kedustaan dan menghalalkan segala cara meskipun harus melanggar syariat agama.

Jika dalam ranah individu dan keluarga masalah terlilit hutang bisa menjadikan ketidakharmonisan, maka dalam ranah perusahaan atau bahkan negara utangpiutang seringkali menjadikan perusahaan pailit dan negara mengalami ketidakstabilan. Jika hutang tanpa bunga saja menjadikan perusahaan bisa pailit apalagi utang-piutang yang ditambah dengan riba atau bunga. Tentu kerusakan yang ditimbulkan jauh lebih parah lagi.
Oleh karena itu, di dalam syariat Islam telah mengatur secara detail tentang muamalah utang piutang. Hal tersebut karena perkara utang bukan perkara yang remeh di dalam Islam. Seringkali perselisihan dan pertikaian bahkan pembunuhan berawal dari perkara utang piutang.

Jika kita lihat dalil-dalil yang ada, perkara hutang bukan sekedar sebatas masalah dunia akan tetapi terkait dengan kebahagian manusia di akhirat. Bukankah seseorang tertunda masuk surga karena masalah hutang? Rasulullah pun pernah menolak menyalatkan seorang sahabat yang meninggal dan masih menanggung hutang.

Dalam realita kekinian, masalah besar dalam muamalah utang kontemporer adalah moratorium pembayaran utang yang dijadikan alat untuk mengambil keuntungan dalam muamalah utang piutang. Semua bank konvensional menggunakan cara ini untuk mendapatkan keuntungan dari utang piutang. Oleh karena itu, bagi orang yang berhutang maupun yang menghutangi hendaknya benar-benar memahami hukum Moratorium dalam pembayaran hutang. Apalagi dalam etika bisnis dimana hampir setiap perusahaan tidak lepas dengan masalah hutang baik jangka pendek, menengah maupun panjang. Dengan demikian muamalah utang-piutang 
menjadi sarana ta'awun dalam kebaikan dan ketaqwaan. Bukan sebagai sarana untuk menzhalimi, mengeksploitasi bahkan merugikan orang lain. Apalagi banyak praktek dilapangan pihak kreditor seringkali tidak mau tahu kondisi penghutang saat meminta penundaan pembayaran hutang. Kasus tukang pukul bayaran saat menagih hutang yang melakukan penganiayaan bahkan pembunuhan merupakan gambaran yang jauh dari konsep inzhar ad dain/ Moratorium dalam Islam.

Bagaimanakah perspektif hukum Islam memandang masalah moratorium dalam pembayaran hutang? Maka makalah dalam jurnal ini akan memaparkan rumusan sebagai berikut:

1. Apakah yang dimaksud dengan moratorium pembayaran hutang dan apa dasar hukumnya di dalam al-Qur'an dan as Sunnah?

2. Syarat apa saja dibolehkan dan dilarang melakukan moratorium dalam tinjuan Islam?

3. Bolehkah memberikan tambahan atau denda keterlambatan utang (Gharamah maaliyah/penalti) dalam moratorium?

4. Bagaimana sanksi hukum Islam bagi orang yang sengaja menunda pembayaran hutang padahal dia rnampu dan orang yang tidak mampu membayar hutang?

\section{B. PEMBAHASAN}

\section{Definisi Moratorium}

Dalam Kamus Besar Bahasa Indonesia ${ }^{1}$, moratorium secara bahasa berarti penundaan atau penangguhan. Namun secara konteks biasanya digunakan dalam penangguhan atau pembayaran utang didasarkan pada undang-undang agar dapat mencegah krisis keuangan yang makin hebat.

Adapun secara istilah Moratorium bisa didefinisikan sebagai suatu proses pemberian tangguh atau penundaan yang dilakukan oleh pemilik piutang kepada penghutang dalam jangka tempo tertentu yang disepakati oleh kedua belah pihak.

\section{A. Perspektif Al Qur'an tentang Moratorium}

Kalau kita kaji didalam al-Qur'an maka akan kita dapati ada satu ayat yang secara khusus menyinggung moratorium dan satu ayat pokok yang meringankan tentang utang-piutang yang secara implisit menerangkan adab-adab terkait dengan moratorium.

\section{b. 1. Ayat yang pertama adalah surat a1}

\section{Baqarah ayat 280}

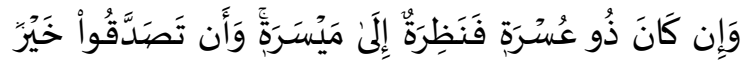

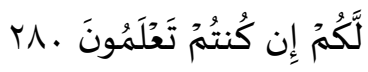

\footnotetext{
${ }^{1}$ Pusat Bahasa, Kamus Besar Bahasa Indonesia, PT. Gramedia Pustaka Utama, Jakarta, 2008, Edisi 4.
} 
"Dan jika (orang yang berhutang itu) dalam kesukaran, maka berilah tangguh sampai dia berkelapangan dan menyedekahkan (sebagian atau sетиа utang itu, lebih baik bagimu, jika kamu mengetahui.,

Ibnu Jarir ath-Thobari dalam tafsirnya ${ }^{2}$ menyebutkan beberapa riwayat tentang sebab turunnya ayat tersebut. Dari riwayat yang ada ayat tersebut turun berkaitan tentang riba. Sebagian riwayat menjelaskan bahwa ayat tersebut berkaitan dengan utangpiutang. Namun beliau menyimpulkan sebagai berikut; "Yang benar ayat ini berkaitan dengan orang-orang jahiliyyah yang kemudian masuk Islam dan mempunyai piutang sedangkan pada waktu itu mereka membungakan uang mereka. Ketiku awal mereka masuk Islam perkara tersebut belum tunai. Maka Alloh perintahkan untuk meninggalkan apa yang berbau riba setelah mereka masuk Islam. Kemudian hanya mengambil uang pokok tanpa tambahan bunga serta memberikan opsi penangguhan (moratorium) dalam pengembalian uang pokok kepada mereka yang berada dalam kesusahan membayar hutang."
Dalam menafsirkan ayat ini Ibnu Katsir berkata: ${ }^{3}$

يأمر تعالى بالصبر على المعسر الذي لا يجد وفاء،

فقال: $\}$ وَإِنْ كَانَ ذُو عُسْرَةٍ فَنَظِرَةٌة إِلَى مَيْسَرَة \{ [أي]: لا

كما كان أهل الجاهلية يقول أحدهم لمدينه إذا حل

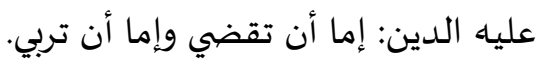

"Alloh SWT memerintahkan bersabar kepada pemilik piutang ketika mendapati orang tua orang yang berhutang padanya dalam kondisi kesusahan untuk pembayaran hutang seraya berkata: "Dan jika (orang yang berhutang itu) dalam kesukaran, Maka berilah tangguh sampai dia berkelapangan" Maksudnya yaitu kita diperintahkan memberikan kelapangan hutang. Tidak seperti apa yang dilakukun di masa jahiliyah yaitu seseorang di antara mereka berkata kepada orang yang berhutang kepadanya, "Jika masa pelunasan utangmu telah tiba, maka adakalanya kamu melunasinya atau kamu menambahkan bunganya."

Dari penjelasan tafsir dari ayat tersebut jelas bahwa di dalam al-Qur'an melarang membungakan uang dalam utang piutang dan itu merupakan riba yang berkembang di zaman jahiliyyah.

Hal ini sebagaimana dalam hadits mauquf yang diriwayatkan oleh al Imam

\footnotetext{
${ }^{2}$ Muhammad Ibnu Jarir ath-Thobari, Jami 'ul Bayan 'An Ta'wil Ayi al-Qur'an, Dar Ibnu Hazm, Juz 3, Hlm, 145.
}

\footnotetext{
${ }^{3}$ Ibnu Katsir, Tafsir al-Qur'an al- 'Adzim, Dar Tayyibah li Nasyri wa Tauzi', 1999, hlm.47.
} 
Baihaqi di dalam bab jual beli dari jalur Yazîd ibn Abî Hubaib dari Abî Marzuq alTajîbi dari Fudalah ibn 'Ubaid bahwasanya dia berkata:

$$
\text { كُلُّ قَرْضٍ جَرَّ مَنْفَعَةً فَهُوَ وَجْهُ مِنْ وُجُوْهِ الرِبِاَ }
$$

"Setiap utang-piutang yang

mendatangkan manfaat maka dia merupakan salah satu bagian dari bagianbagian riba". (H.R. al-Baihaqi: 5/350) ${ }^{4}$

Meskipun hadits tersebut mauqûf namun hadits tersebut maknanya shahih dan digunakan sebagai kaidah dalam akad qard. Ibn 'Âbidîn dalam hasyî'ah-nya menyebutkan satu pembahasan yang sangat penting yaitu:

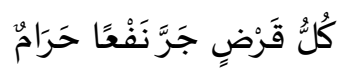

"Setiap utang-piutang yang mendatangkan manfaat adalah haram."

Maksud dari qard yang mendatangkan manfaat adalah yang disyaratkan sejak awal akad. ${ }^{5}$

${ }^{4}$ Adapun lafadz hadits yang berbunyi:

$$
\text { كُلُّ قَرْضِ جَرَّ مَنْفَعَةً فَهُوَ الرِِّاَ }
$$

"Setiap akad utang piutang yang mendatangkan manfaat maka dia riba"

Hadits ini dijelaskan Ibnu Hajar haditsnya tidak shohih. al-Nawawy, Muhyiddin ibn Syarf, alMajmû' Syarhn al-Muhadzdzab, Dâr al-Fikr, Beirut, 1996, cet.1, juz 13 hlm. 234

${ }^{5}$ al-Tamratâsyi, Syams al-Dîn, Râd al-Muhtâr 'Alâ Dâr al-Mukhtâr, hasỵ̂'ah ibn 'Âbidinn. 'Alâ Syarh Syaikh 'Alâ al-Din Muhammad ibn 'Ali alHashkafy, Dâr al-Ma'rîfah, Beirut, 2000, cet.1 Juz 7, hlm. 413.
Dari hadis tersebut akhirnya para ulama membuat sebuah kaidah ushul fiqih dalam masalah riba sebagai berikut:

$$
\text { كل قرض جر نفعا فهو ربا }
$$

"Setiap pinjaman yang menghasilkan manfaat adalah riba." 6

\section{b.2. Surat a1-Baqoroh ayat 282}

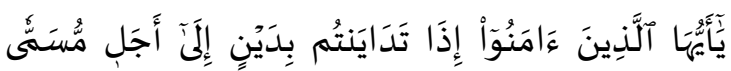

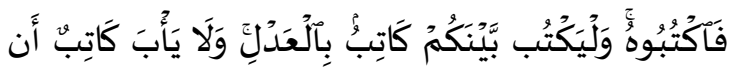

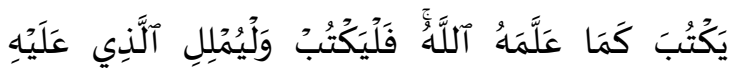

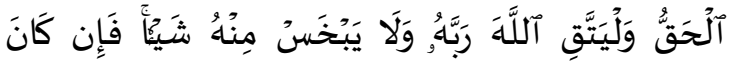

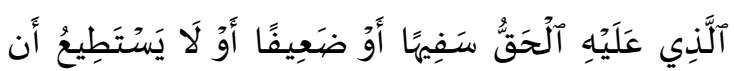

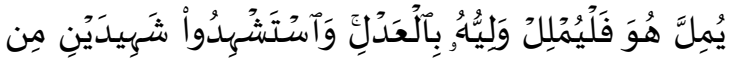

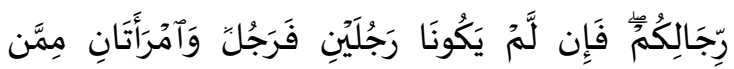

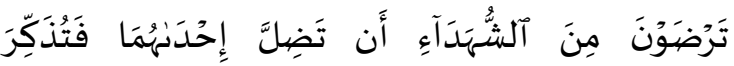

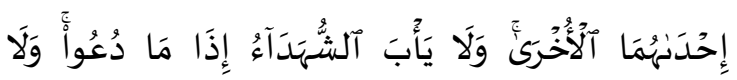

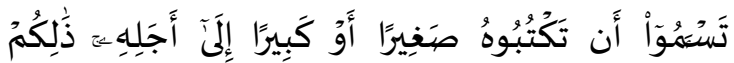

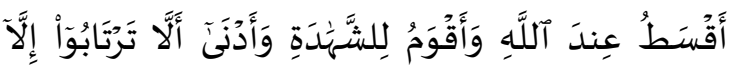

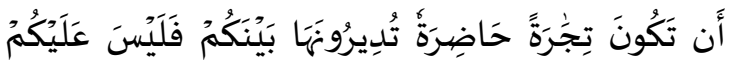

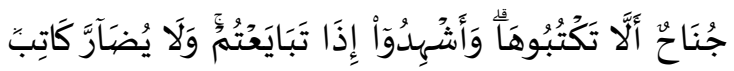

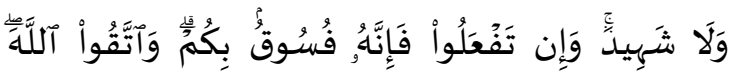

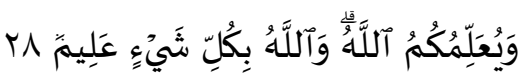

\footnotetext{
${ }^{6}$ Tahir, Muhammad Mansoori, KaidahKaidah Keuangan dan Transaksi Bisnis, Ulil Albaab Institute Pasca Sajana Universitas ibnu Khaldun, Bogor, 2010, HIm. 195.
} 
"Hai orang-orang yang beriman, apabila kamu bermu'amalah tidak secara tunai untuk waktu yang ditentukan (utangpiutang), hendaklah kamu menuliskannya. dan hendaklah seorang penulis di antara kamu menuliskannya dengan benar. dan janganlah penulis enggan menuliskannya sebagaimana Allah mengajarkannya, maka hendaklah ia menulis, dan hendaklah orang yang berhutang itu mengimlakkan (apa yang akan ditulis itu), dan hendaklah ia bertakwa kepada Allah Tuhannya, dan janganlah ia mengurangi sedikitpun daripada hutangnya. jika yang berhutang itu orang yang lemah akalnya atau lemah (keadaannya) atau Dia sendiri tidak mampu mengimlakkan, Maka hendaklah walinya mengimlakkan dengan jujur. dan persaksikanlah dengan dua orang saksi dari orang-orang lelaki (di antaramu). jika tak ada dua orang lelaki, Maka (boleh) seorang lelaki dan dua orang perempuan dari saksi-saki yang kamu ridhai, supaya jika seorang lupa Maka yang seorang mengingatkannya. Janganlah saksi-saksi itu enggan (memberi keterangan) apabila mereka dipanggil; dan janganlah kamu jemu menulis hutang itu, baik kecil maupun besar sampai batas waktu membayarnya. yang demikian itu, lebih adil di sisi Allah dan lebih menguatkan persaksian dan lebih dekat kepada tidak (menimbulkan) keraguanтu. (Tulislah mu'amalahmu itu), kecuali jika muamalah itu perdagangan tunai yang kamu jalankan di antara kamu, maka tidak ada dosa bagi kumu, (jika) kamu tidak menulisnya. dan persaksikanlah apabila kamu berjual beli; dun janganlah penulis dun saksi saling sulit menyulitkan. jika kamu lakukan yang demikian), Maka Sesungguhnya hal itu adalah suatu kefasikan pada dirimu. dan bertakwalah kepada Allah; Allah mengajarmu; dan Allah Maha Mengetahui segala sesuatu."

Ayat ini sering disebut oleh para ulama dengan ayat ad-Dain (utang-piutang). Dan hakikat dari hutang adalah sebagai berikut: عبارة عن كل معاملة كان أحد العوضين فيها نقدا والأخر في الذمة نسيئة

"Suatu ibarat dari segala bentuk muamalah dimana salah satu pihak menyerahkan kepada pihak lain berupa uang sedangkan uang tersebut bagi pihak yang diserahkan menjadi tanggungannyu yang dikembalikan (dibayar) secara tertunda pada temponya.,7

Berkaitan dengan ayat ini Imam Ibnu $\mathrm{Katsir}^{8}$ ketika rnenjelaskan ayat ini dalam tafsirnya;

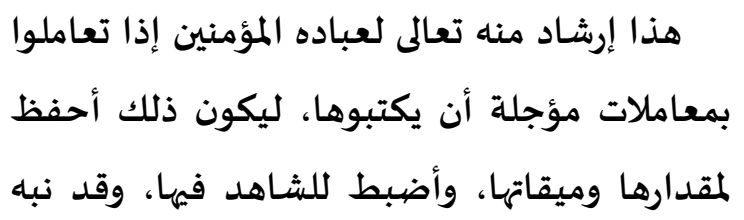

${ }^{7}$ Abdullah, Muhammad Ibnu a1 A'robi, Ahkam al-Qur'an, Dar a1-Kutub al I'lmiyyah, Beirut, Juz I, hlm, 327.

${ }^{8}$ Ismai1, Ibnu Umar lbnu Katsir, Tafsir al Qur'an al Adzim, Dar a1-Salam li Nasyri wa Tauzi', Riyadh, Juz 1, Hlm. 462. 


\section{على هذا في آخر الآية حيث قال: \} ذَلِكُمْ أَقْسَطُ عِنْدَ

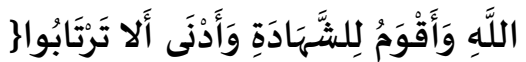

"Hal ini merupakan petunjuk dari Allah SWT buat hamba-hamba-Nya yang mukmin apabila mereka mengadakan muamalah secara tidak tunai, yaitu hendaklah mereka mencatatkannya; karena catatan itu lebih memelihara jumlah barang dan masa pembayarannya serta lebih tegas bagi orang yang menyaksikannya. Hikmah ini disebutkan dengan jelas dalam akhir ayat, yaitu melalui Firman-Nya: "Yang demikian itu lebih adil di sisi Allah dm lebih dapat menguatkan kesaksian dan lebih dekat kepada tidak' (menimbulkan) keraguan kalian. (Al-Baqarah: 282).

Adapun Abdurrahman as-Sa'di dalam tafsirnya ${ }^{9}$ menjelaskan banyak faidah dari ayat ini yang seharusnya di ketahui bagi orang-orang yang terlibat dalarn utang piutang.

1. Dibolehkan muamalah dengan utang-piutang baik utang secara murni maupun dalam pembelian secara kredit.

2. Wajib menentukan waktu tempo pembayaran dari utang tersebut.

3. Apabila waktu tempo pembayaran hutang tidak ditentukan maka hal

${ }^{9}$ Ibnu Nashir as-Sa'di, Abdurmahman, Taisir Karimi ar Rahman fi Tafsir kalam al Manan, Muasasah ar Risalah, Beirut, 1996. Hlm. 98-99. tersebut tidak halal karena merupakan ghoror (adanya unsur penipuan/keculasan).

4. Perintah Alloh kepada notulen agar mencatat orang yang saling berhutang dengan adil tidak condong karena kekerabatan dan tidak mendzolimi karena kebencian.

5. Bahwasanya notulensi utang-piutang antar kedua belah pihak merupakan sebaik-baik amal dan merupakan bentuk perbuatan lhsan kepada keduanya. Dan didalamnya menjaga hak-hak kedua belah pihak.

6. Bahwasanya notulen wajib mengetahui keadilan dan terkenal sebagai seorang yang berperilaku adil.

7. Pihak yang meminta pencatatan adalah pihak yang berhutang.

8. Bahwasanya persaksian dua orang wanita dalam masalah utang setara dengan persaksian satu laki-laki. Hal ini adalah dalam persaksian yang menyangkut perkara duniawi. Adapun dalam masalah din seperti periwayatan, berfatwa maka kesaksian perempuan setara dengan laki-laki.

9. Tidak boleh mengambil upah dalam penulisan dan kesaksian utang karena hal tersebut merupakan perkara yang telah di wajibka Alloh. Dan hal tersebut 
merupakan keburukan bagi 2 pihak yang saling bertentangan.

10. Bahwasanya melukai atau mencederai saksi dan notulen maka ha1 tersebut termasuk tindak kefasikan dan lain-lainnya.

\section{B. Perspektif As-Sunnah tentang Moratorium}

Banyak sekali hadis Nabi Sallallahu 'alaihi wassalam yang menjelaskan tentang Moratorium dalam pembayaran hutang di antaranya adalah:

1. Hadits Ibnu Abbas radhiyallahu 'anhuma dalam riwayat a1-Bukhori ${ }^{10}$ dan Muslim. ${ }^{11}$

عَنْ ابْنِ عَبَّاسِ رَضِيَ اللَّهُ عَنْهُمَا قَالَ قَدِمَ النَّبِيُّ صَلَّى

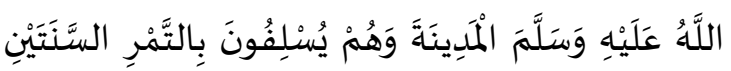
وَالثَّلَاثَ فَقَالَ مَنْ أَسْنَفَ فِي شَيٍٍِْ فَفِي كَيْلٍ مَعْلُوٍِ

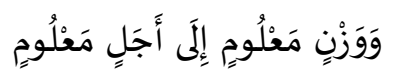

"Dari Ibnu Abbas yang menceritakun bahwa ketika Nabi Sallallahu alaihi wassalam tiba di Madinah, para penduduknya telah terbiasa saling mengutangkan buah-buahan untuk masa satu tahun, dua tahun, sampai tiga tahun. Maka Rasulullah Sallallahu 'alaihi

10 Ibnu Ismail al-Bukhori, Muhammad, alJami’ ash-Shahih, Daral Sya'b, Mesir, 1987, Juz 3, hlm 111, Hadits nomer: 2240.

${ }^{11}$ Ibnu Hajjaj, Muslim, Shahih Muslim, Dar ihya' a1 Turots a1 'Arobi, Beirut, Juz 3, Hlm. 1226. Hadis nomor: 1604. wassalam bersabda, "Barang siapa yang berutang, maka hendaklah ia berutang dalam takaran yang telah dimaklumi dan dalam timbangan yang telah dzmaklumi untuk waktu yang ditentukun."

2. Hadits riwayat ath-Thabrani ${ }^{12}$ dari Abu Urnamah (yaitu As'ad ibnu Zurarah), bahwa Rasulullah Sallallahu 'alaihi wassalam pernah bersabda:

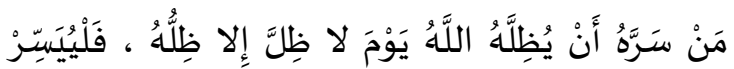

$$
\text { عَلَى مُعْسِرٍ أَوْ لِيَضَتْعُ عَنْهُ }
$$

"Barang siapa yang ingin mendapat naungan dari Allah pada hari tiada naungan kecuali hanya naungan-Nya, maka hendaklah ia memberikun kemudahan kepada orang yang dalam kesulitan atau memaafkan utangnya. (HR. ath-Thabrani)

3. Hadis riwayat $\mathrm{Ahmad}^{13}$ dari Sulaiman Ibnu Buraidah al-Aslami dari bapaknya.

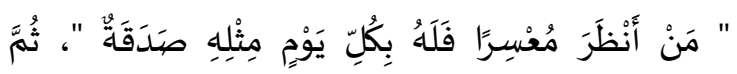

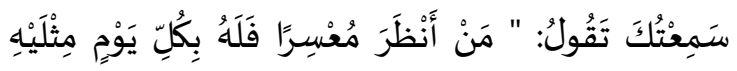

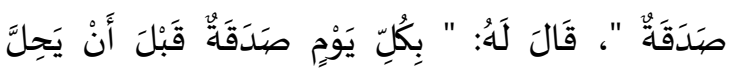

\footnotetext{
${ }^{12}$ Ibnu Ahmad ath-Thobroni, Sulaiman, Mu'jam al Thobroni, maktabah a1-Ulum wa al hikam, Irak, 1983, juz 1, Hlm. 304. Hadis nomor: 899.

${ }^{13}$ Ibnu Hambal, Ahmad, Musnad Imam Ahmad, Muasasah a1-Qurtubah, Juz 5, Hlm 360, Hadits nomor: 23096.
} 


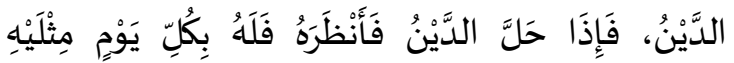

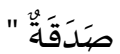

"Barangsiapa yang memberikan tempo bagi orang yang kesulitan membayar hutang maka ia setiap hari bersedekah sebesar uang yang dihutangkannya. Kemudian aku mendengarmu bersabda, 'Barangsiapa yang memberikan tempo bagi orang yang kesulitan membayar hutang maka ia setiap hari bersedekah sebesar uang yang dihutangkannya.' Maka, nabi berkata kepadanya, 'Setiap hari ia bersedekah sebelum hutangnya lunas. Apabila datang temponya kemudian ia memberikan kelonggaran maka baginya pahala bersedekah setiap hari dua kali lipat."

Jadi, dari hadis-hadis tersebut menjelaskan bahwa moratorium pembayaran utang dibolehkan dan merupakan amalan ibadah yang agung pahalanya. Hanya saja, hal tersebut harus dilakukan sesuai dengan syarat dan ketentuan yang ada.

\section{Syarat-Syarat Dibolehkan dan Dilarang Moratorium}

\section{Kondisi Dibolehkan Moratorium}

\section{Pembayaran Utang}

Jika kita kaji dalil-dalil dari a1-Qur'an dan as-Sunnah yang telah dipaparkan di atas, maka Moratorium pembayaran utang dibolehkan dalam ajaran Islam. Bahkan sangat dianjurkan ketika kondisi penghutang dalam keadaan kesulitan. Namun demikian, paling tidak ada 5 syarat yang harus dipenuhi ketika melakukan Moratorium atau penundaan pembayaran hutang.

a. Kondisi Penghutang benar-benar dalam keadaan tidak mampu untuk membayar hutang.

b. Terdapat kesepakatan antara kedua belah pihak untuk melakukan penundaan pembayaran hutang.

c. Jangka dan tempo pembayaran hutang jelas.

d. Tidak adanya tambahan bunga atau syarat manfaat lainnya ketika jatuh tempo pembayaran utang.

e. Akad Moratorium tersebut didasari atas keridhaan antara kedua belah pihak. Artinya adanya kesiapan dalam menanggung resiko atas keterlambatan oleh kedua belah pihak.

\section{Kondisi Dilarang Melakukan}

\section{Moratorium Pembayaran Hutang}

Hukum asal dalam muamalah utangpiutang adalah dibayar ketika jatuh temponya. Adapun ditempuh Moratorium adalah sebagai solusi bijak ketika terjadi ketidakmampuan sang penghutang untuk membayar hutang ketika jatuh tempo. Akan tetapi ada beberapa kondisi opsi moratorium dilarang di dalam tinjauan Islam. Di antaranya yaitu: 
1. Penghutang dalam kondisi mampu untuk membayar hutang ketika jatuh tempo akan tetapi ia sengaja menunda-nunda pembayarannya.

Dalam hal ini Rosululloh Sallallahu 'alaihi wassalam bersabda dalam hadis riwayat Muslim ${ }^{14}$

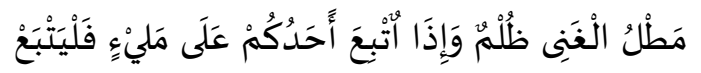

"Menunda-nunda pembayaran hutang dalam keadaan suatu kedzaliman. Dan apabila hutang tersebut dialihkan kepada orang kaya dan terpercaya yang siap menanggung (anjak piutang) maka hendaknya ia menerima hal tersebut."

Di dalam kitab 'Ainul Ma'bud ${ }^{15}$ Maksud dari adalah mengakhir-kan pembayaran utang dari waktu ke waktu. Maksud dari kezhaliman atau (ظلم) adalah penundaan pembayaran hutang (Moratorium) pada dasarnya mencegah pelaksanaan kewajiban yang seharusnya dilakukan dan ini merupakan sesuatu yang haram dari seseorang yang mampu walaupun dia seorang yang kaya. Namun demikian, tidak berarti pula bahwa orang yang miskin boleh menunda-nunda ketika sanggup membayar hutangnya.
Hadits yang senada dengan hadits di atas adalah Hadis Amr Bin Syarid.

$$
\text { لََيٌْ الْوَاجِدِ يُحِلُّ عِرْضَهَهُ وَعُقُوبَتَهُ }
$$

"Orang kaya yang menunda-nunda pembayaran hutangnya maka boleh dicemarkan reputasinya dan diberi sanksi hukuman." (HR. Abu Dawud dan Nasa'i) ${ }^{16}$

Dari dalil hadits di atas menunjukkan tentang keharaman Moratorium pembayaraan hutang ketika dalam keadaan mampu. Adapun larangan Moratorium selain poin di atas pada dasarnya kebalikan dari poin-poin dibolehkannya Moratorium seperti yang telah disebutkan:

a. Tidak adanya kesepakatan antara kedua belah pihak untuk melakukan moratorium.

b. Jangka dan tempo pembayaran hutang tidak jelas.

c. Adanya tambahan bunga atau syarat manfaat lainnya ketika jatuh tempo pembayaran.

d. Akad Moratorium tersebut tidak didasari atas keridhoan antara kedua belah pihak.

\section{Hukum Tambahan Manfaat dan Denda (Penalty) dalam Moratorium Pembayaran Hutang}

\footnotetext{
${ }^{16}$ Lukman al Salafi, Muhammad, Tuhfalul Kirom Syarah Bulughul Marorn, Dar al Da'i li Nasyri wa Tauzi, Riyadh, 2000, Hlm. 539, Hadits Nomor: 838.
} 
Sebelum kita membahas bagaimana hukumnya, maka dalam hal ini perlu kita bedakan antara istilah 'tambahan manfaat' dan 'denda/penalty' dalam pembayaran hutang. Walaupun keduanya hampir mirip dalam istilah namun dalam prakteknya keduanya memiliki hakikat yang berbeda jika kita rinci.

\section{Tambahan manfaat}

Tambahan yang dimaksudkan disini bukan sekedar hanya uang akan tetapi segala manfaat yang dikaitkan dengan utang piutang tersebut. Dalam hal ini perlu kita pahami kaidah yang penting yang telah disebutkan sebelumnya juga berkaitan dengan utang-piutang.

$$
\text { كل قرض جر نفعا فهو ربا }
$$

"Setiap pinjaman yang menghasilkan manfaat adalah riba"

Syariah tidak membolehkan kepada pemberi pinjaman untuk mengambil pendapatan dan manfaat apapun dari pinjaman yang diberikan kepada peminjam hutang. Manfaat itu adalah riba yang dilarang dalam pandangan syariah. Namun maksud dari manfaat yang dilarang di dalam kaidah tersebut adalah manfaat yang telah ditentukan dan disyaratkan di awal akad.

Di dalam Al Mughn ${ }^{17} i$ Ibnu Qudamah rahimahullah membuat satu pembahasan

\footnotetext{
${ }^{17}$ Ibnu Qudamah, Al Mughniy, Maktabah Al Qahirah, juz 4, hlm. 240. (Al Maktabah Asy Syamilah)
}

yang penting tentang syarat tambahan dalam berhutang. Dalam penjelasan tersebut beliau mengatakan bahwa terdapat ijma' dalam pengharaman tambahan tersebut.

$$
\begin{aligned}
& \text { وَكُلُّ قَرْضٍ شَرَطَ فِيِه أَنْ يَزِيدَهُ، فَهُوَ حَرَامَ، بِغَيْرِ }
\end{aligned}
$$

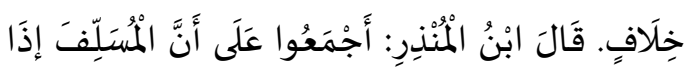

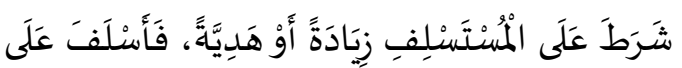

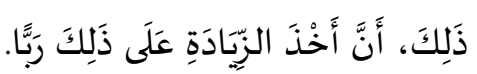

"Setiap utang yang dipersyaratkan ada tambahan, maka itu adalah haram. Hal ini tanpa diperselisihkan oleh para ulama. Ibnul Mundzir rahimahullah berkata, 'Para ulama sepakat bahwa jika seseorang yang meminjamkan utang dengan mempersyaratkan kepada penghutang hadiah atau tambahan, lalu ia meminjamkannya dengan mengambil tambahan atau hadiah tersebut, maka itu adalah riba."

Sebagai contohnya adalah sebagai berikut. "Saya akan pinjami kamu uang akan tetapi kamu harus pinjamkan sepeda motor kamu kepada saya." Tambahan manfaat seperti peminjaman motor dalam kasus tersebut yang disyaratkan di awal adalah bentuk riba yang dilarang. Tambahan manfaat yang disyaratkan itulah yang dimaksudkan di dalam kaidah ini.

Adapun tambahan yang bersifat suka rela dan tidak dipersyaratkan dalam akad utang piutang maka hal tersebut dibolehkan. Seperti ketika orang yang meminjam utang saat mengembalikan ia memberi tambahan 
sebagai tanda terimakasih akan tetapi tembahan tersebut benar-benar murni tidak disyaratkan di dalam akad. Adapun dalil pembolehan ini adalah hadits dari Abu Hurairah dalam Shahih Bukhari. ${ }^{18}$

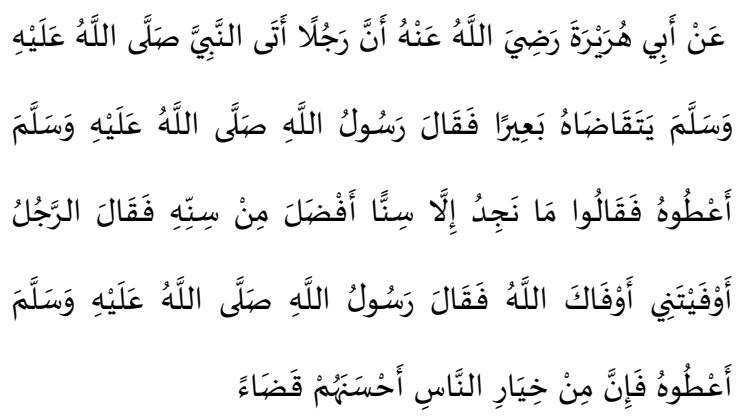

"Abu Hurairah meriwayatkan sebuah hadis bahwa seorang laki-laki mendatangi Nabi sallahu 'alaihi wassalam untuk menagih utang unta kepada Rosulullah sallahu 'alaihi wassalam, maka Rosulullah sallahu 'alaihi wassalam berkata, 'Kembalikan untanya.' Para sahabatpun berkata, 'Kami tidak mendapati unta kecuali unta yang lebih bagus dari kualitas untanya dari sisi usianya. Maka laki-laki itu berkata, 'Lunasilah utangku semoga Allah melunasimu.' Maka Rosulullah sallahu 'alaihi wassalam bersabda, 'Berikan unta yang lebih berkualitas itu. Sesungguhnya sebaik-baik manusia adalah yang paling baik dalam melunasi utang."

Jadi, jelas sekali bahwa tambahan manfaat yang dilarang adalah yang dipersyaratkan di dalam akad. Adapun

\footnotetext{
${ }^{18}$ Al Bukhari, Muhammad bin Ismail, Shahih al Bukhari, Dar Ibn Katsir, Beirut, 1987, Juz 2, hlm. 843. Nomor hadis 2263.
}

tambahan atau hadiah yang murni tidak dipersyaratkan bukan termasuk riba.

\section{Denda (penalty)}

Denda keterlambatan utang atau penalty di dalam bahasa arab disebut dengan alGhoromah al-Maliyyah. Biasanya denda atau penalty ini diberlakukan ketika keterlambatan utang dianggap memberi madhorot atau kerugian yang dialami oleh debitur. Memang Moratorium seringkali berdampak negatif kepada debitur baik dalam pembelanjaan harta maupun investasi lainnya. Moratorium sendiri secara esensi merupakan bentuk dari madharat yang terkadang berimplikasi pada kerugian sektor lain di bawahnya. Atau bahkan berpengaruh pada perolehan keuntungan atau ekspektasi yang mungkin bisa dipastikan karena siklus cash flow keuangan yang rutin ketika tidak terjadi keterlambatan pembayaran hutang dalam perusahaan. Namun demikian, seringkali prakteknya tidak jauh beda dengan sistem riba jahiliyah.

Dalam hal ini maksud dari madharat adalah lawan dari manfaat. Bisa juga diartikan segala dampak negatif yang muncul dari Moratorium. Secara global kemudharatan yang biasanya mengakibatkan denda terbagi menjadi dua:

a. Kemudhorotan/dampak negatif yang ditimbulkan karena murni penundaan dan tidak terkait dengan ekspektasi 
keuntungan yang pasti bisa diraih dengan penundaan hutang tersebut.

Dalam kasus ini seperti dalam kasus kredit yang terjadi di bank konvensional. Nasabah dikenakan denda berupa tambahan bunga dari cicilan yang dibayarkan setiap bulannya. Hal ini merupakan praktek dari riba yang dilarang dalam Islam. Atau seperti praktek perorangan seperti perkataan sang pemberi hutang kepada penghutang, 'Jika kamu terlambat membayar hutang pada tempo yang disepakati, maka akan kami denda dari keterlambatan tersebut 5\% dari jumlah hutang.' Praktek seperti ini jelas-jelas praktek riba yang dilarang di dalam Islam.

b. Denda disebabkan kemadharatan akan hilangnya keuntungan yang kemungkinan besar bisa dipastikan diperoleh jika tidak terjadi keterlambatan hutang.

Keterlambatan pembayaran hutang terkadang membawa madharat besar jika ruang lingkupnya adalah investasi perusaham besar pula. Contohnya seperti seseorang yang menjual mobil dengan harga 100 juta rupiah secara murobahah dengan keuntungan 10 persen dan akan dibayar selama setahun. Ternyata sang pembeli menunda pembayaran hingga dua tahun. Seandainya pembeli melunasi pada temponya bisa dipastikan penjual akan mendapatkan keuntungan 20 persen selama dua tahun dari uang tersebut.
Apakah dalam hal ini sang penjual boleh memberikan denda?

Pada kasus ini para ulama kontemporer berbeda pendapat antara melarang dan membolehkan. Pendapat yang melarang berdalil bahwa tidak bolehnya mendenda orang yang berhutang dan mampu melunasi dengan membayar denda kerugian yang tidak disyaratkan di akad karena penundaan pembayaran. Pendapat ini merupakan pendapat a1-Majma' Al Fiqhi dan mayoritas ulama kontemprer. Adapun ulama yang membolehkan seperti Syaikh Abdullah al Mani' dan Musthofa Ahmad al-Zarqa' dengan alasan salah satunya karena hal tersebut tidak bertentangan dengan syariah bahkan pelakunya ibarat orang yang men-ghasab (mengambil paksa) harta orang lain ${ }^{19}$. Terlepas dari perbedaan tersebut berlepas diri dari khilaf jauh lebih selamat. Sebab masalah ini tentu sangat butuh penelitian khusus dan kajian ekonomi yang mendalam dari berbagai macam segi.

\section{E. Sanksi Hukum Bagi Orang Yang Menunda Atau Tidak Bisa Membayar Hutang}

1. Sanksi bagi orang yang menunda membayar hutang dalam keadaan mampu

\footnotetext{
${ }^{19}$ Lihat tulisan Dr. Sulaiman Ibnu Sholih a1 Daakhil, al Ta 'widh 'an al Adhror al Mutarottabah al Mumatholah al Duyun, http://www.saaid.net.
} 
Rosululloh Sallahu 'alaihi wassalam bersabda:

$$
\text { لَيٌْ الْوَاجِدِ يُحِلهُ عِرْضَهَهُ وَعُقُوبَتَهُ }
$$

"Orang kaya yang menunda-nunda pembayaran hutangnya patut diumumkan dicemarkan reputasinya (nama baiknya) dan diberi sanksi hukuman. (HR. Abu Dawud dan Nasa'i)

Dalam menjelaskan hadits ini Syaikh Hasan Ayyub ${ }^{20}$ menukil perkataan Ibnu alMubarak, "Maksud dari (يحل عرضاه) adalah orang yang menunda-nunda tersebut berhak mendapatkan tekanan untuk membayar hutang dan ketika dipengadilan dia boleh dikatakan sebagai seorang yang zhalim, Adapun makna (وعقوته) yaitu dia dikenai sanksi kurungan sampai dia membayar hutangnya. Kemudian dia menjelaskan bahwa orang yang tidak mampu maka tidak berhak mendapatkan kurungan dipenjara. Sebab ia bukanlah orang zhalim karena belum mampu membayar.

Apabila orang yang mampu tersebut menyembunyikan kekayaannya, maka hakim berhak memenjarakannya bahkan memberikan hukuman lain sampai mengeluarkan hartanya. Apabila ia beralasan hartanya hilang, maka alasan tersebut tidak bisa diterima sampai ada bukti yang akurat. Apabila ternyata ia

\footnotetext{
${ }^{20}$ Hasan Ayub, Fiqh al Mu'amalat al Maliyah al lslami, Dar al Salam, Mesir, 2006, Hlm.180.
}

tidak ada bukti yang jelas, maka berhak dipenjara. Adapun tujuan memenjarakan tersebut semata-mata hanya untuk mencari kejelasan harta kekayaannya. Jika ternyata benar-benar didapati tidak ada hartanya, maka ia wajib dibebaskan."

\section{Sanksi bagi orang yang tidak membayar hutang}

\section{a. Sanksi di Dunia}

Orang yang tidak membayar hutang, maka di dunia dia berhak mendapat sanksi berupa pelarangan pembelanjaan harta (penyitaan) atau harta tersebut dijual dan digunakan untuk melunasi hutanghutangnya. Dalam hal ini terdapat hadis tentang kisah Mua'adz bin Jabal Radhiallahu anhu.

$$
\begin{aligned}
& \text { "كان معاذ بن جبل شابا سخيا وكان لا يمسك شيئا } \\
& \text { فلم يزل يدان حتى أغلق ماله في الدين فأتي النبي - } \\
& \text { صَلَّى اللهُ عَلَيِِْهِ وَسَلَّمَ - فكلمها ليكلم غرماءه، فلو تركوا } \\
& \text { لأحدد لتركوا لمعاذ لأجل رسول الله - صَلَّى اللهُ عَلَيْهِ }
\end{aligned}
$$

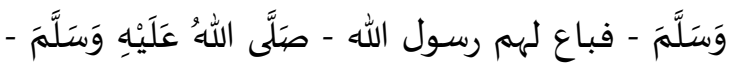

$$
\begin{aligned}
& \text { لهم ماله حتى قام معاذ بغيره شيء". وهو حديث } \\
& \text { ضعيف انظر: "الإوراء" رقم (1435 }
\end{aligned}
$$

“Bahwasanya Mu’adz ibnu Jabal seorang pemuda yang pemurah akan tetapi ia tidak memiliki apa-apa. Dan dia seorang yang senantiasa berhutang hingga seluruh hartanya dan barang-barangnnya habis untuk keperluan hutang. Maka Nabi 
Sallahu Alaihi Wassalam datang dan menyarankan agar dia membicarakannya dengan pemilik harta. Seandainya mereka seтиa meninggalkan/ memaafkan hutang tersebut (seolah-olah semua itu karena kedudukannya disisi Rosululloh Sallahu Alaihi Wassalam saja) Maka Rosululloh Sallahu Alaihi Wassalam menjual barangbarang milik Mua'adz dan memberikan kepada pemilik hutang untuk melunasinya hingga pada saat itu Mu'adz tidak punya harta sedikitpun." (HR. Said di dalam Sunannya. Hadis ini didhaifkan Syaikh Albani di dalam Al Irwa' no. 1435)

Dalam menjelaskan hadits ini Imam asy-Syaukani ${ }^{21}$ mengatakan "Bahwasanya dibolehkan menyita bagi orang yang tidak maтри membayar hutang dan di bolehkannya bagi hakim menjualnya untuk menutupi hutangnya tanpa harus membedakan apakah hutang tersebut banyak atau sedikit."

Ibnu Qudamah berkata di dalam 'Al Mughni $^{22}$,

"ومتى لزم الإنسان ديون حالة لا يفي ماله بها، فسأل

غرماؤه الحاكم الحجر عليه، لزمته إيجابتهم ويستحب

\footnotetext{
${ }^{21}$ Ibnu 'Ali Ibnu Muhammad asy-Syaukani, Muhammad, Nailul al Author min Ahaadits Sayyidu al Ahyar Syarh Muntaqo aI Akhbar, Dar Ibnu Hazm, Beirut, 2000, Hlm.1099, Hadits nomor: 2315.

${ }^{22}$ Ibnu Qudamah, Al Mughni, Darul Fikr, Beirut, 1405 H, Juz 4 hlm.493.
}

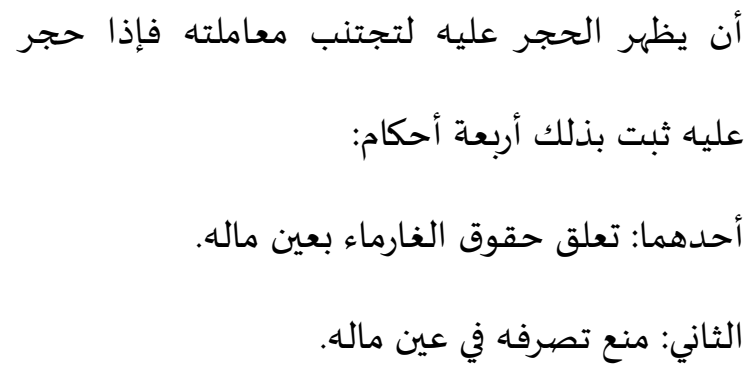

"Kapan saja seseorang wajib melunasi hutangnya akan tetapi tidak mampu melunasinya kemudian orang menghutanginya meminta kepada hakim untuk menyita hartanya, maka wajib bagi hakim untuk merealisasikannya. Dianjurkan pula untuk menampakkan penyitaan atasnya agar orang lain menghindar dari bermuamalah dengannya. Apabila telah disita asetnya maka ada empat hukum terkait atasnya:

1. Hak-hak orang yang dihutangi terkait dengan harta atau aset yang ada.

2. Ia dilarang menggunakan hartanya (yang disita)

3. Siapa saja dari orang yang dihutangi yang mendapati asset orang yang berhutang tersebut maka ia lebih berhak dengan asset tersebut dari orang lain yang juga berhutang ketika ada syarat-syarat terkait dengannya. 
4. Bagi hakim untuk menjual asetnya dan melunasi orang-orang yang dihutanginya dan hukum asal ini sebagaimana yang diriwayatkan oleh Ka'ab bin Malik Radhiallahu 'anhu.

Setelah disita harta tersebut maka bagi hakim segera menjual dan membaginya kepada pemilik hutang. Hal tersebut sebagaimana yang di jelaskan oleh al Khatib asy Syarbini dalam Mughni al Muhtaj. ${ }^{23}$

يبادر القاضي بعج الحجرببيع ماله وقسماه بين الغرماء، و يقدم ما بخاف فساده، ثم الحيوان ثم المنقول فم العقار "Hendaknya hakim bersegera menjual aset yang disita dari orang yang tidak bisa membayar tersebut serta membagikan kepada pemilik hutang. Penjualan aset dimulai dari barang-barang yang mudah rusak kemudian hewan-hewan, kemudian barang yang bisa dipindahkan baru kemudian tanah dan bangunan."

\section{b. Sanksi Akhirat}

Adapun sanksi akhirat maksudnya sanksi yang diberikan Allah di hari akhirat terhadap mereka yang tidak membayar hutangnya di dunia. Dalam hal ini ada beberapa hadits yang menjelaskan bahwa dosa hutang akan senantiasa dibawa mati

${ }^{23}$ Muhammad Ibnu al Khotib asy Syarbini, Syamsuddin, Mughni al Muhtaj ila Ma'rifati Ma'ani al Alfadz al Minhaj, Dar al Fikr, Beirut, 1998, h. 205. walaupun seseorang mati syahid di jalan Allah. Rosululloh Sallahu Alaihi Wassalam bersabda:

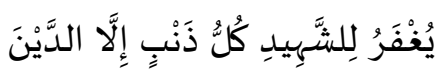

"Diampuni bagi orang yang mati Syahid seluruh dosanya kecuali dosa yang berkaitan dengan utang-piutang." (HR.Muslim) $^{24}$

Hadis ini menunjukkan betapa pentingya memenuhi hak sesama manusia, terutama masalah uang, sampai seorang yang mati syahid pun tidak mendapatkan pengampunan walaupun berulang kali ia mati syahid. $^{25}$

Hadis yang senada dengan hadis di atas adalah:

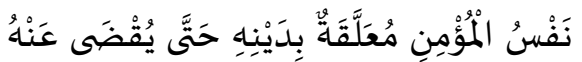

"Jiwa seorang Mukmin akan senatiasa menggantung dengan hutangnya sehingga dia melunasinya." (HR. at-Tirmidzi) ${ }^{26}$

Itulah beberapa sanksi bagi mereka yang tidak mampu membayar hutang setelah dilakukan moratorium kepada mereka.

\footnotetext{
${ }^{24}$ Ibnu Hajaj, Muslim, Shahih Muslim, Dar al Jiil, Beirut, Juz 6, Hlm.38, Hadits nomor: 4392.

25 Qardhawi, Yusuf, Norma dan Etika Ekonomi Islami, Gema Insani Press, Jakarta, 1997, Hlm. 149.

${ }^{26}$ Ibnu Isa at Tirmidzi, Muhammad, al Jami' al Shahih Sunan at Tirmidzi, Dar Ihya at Turats al 'Arabiy, Beirut, Juz 3, Hlm 389. Hadits nomor: 1078 .
} 


\section{F. PENUTUP}

Dari pembahasan tersebut dapat kita ambil kesimpulan sebagai berikut:

1. Definisi Moratorium secara bahasa berarti penundaan atau penangguhan. Namun secara konteks biasanya digunakan dalam penangguhan atau pembayaran utang didasarkan pada undang-undang agar dapat mencegah krisis keuangan yang makin hebat.

Adapun secara istilah moratorium bisa didefinisikan sebagai suatu proses pemberian tangguh atau penundaan yang dilakukan oleh pemilik piutang kepada penghutang dalam jangka tempo tertentu yang disepakati oleh kedua belah pihak.

Dasar hukum dari Moratorium dalam a1-Qur'an adalah surat al-Baqoroh ayat 280 dan 282. Adapun dalil dari hadits diantaranya Hadis Ibnu Abbas radhiyallohu 'anhuma dalam riwayat alBukhori dan Muslim "Dari Ibnu Abbas yang menceritakan bahwa ketika Nabi Sallahu Alaihi Wassalam. tiba di Madinah para penduduknya telah terbiasa saling mengutangkan buah-buahan untuk masa satu tahun, dua tahun, sampai tiga tahun. Maka Rosululloh Sallahu Alaihi Wassalam bersabda, "Barang siapa yang berutang, maka hendaklah ia berutang dalam takaran yang telah dimaklumi dan dalam timbangan yang telah dimaklumi untuk waktu yang ditentukan.
2. Syarat -syarat yang harus dipenuhi ketika melakukan Moratorium atau penundaan dalam pembayaran hutang adalah sebagai berikut:

a. Kondisi Penghutang benar-benar dalam keadaan tidak mampu dalam pembayaran hutang.

b. Adanya kesepkatan antara kedua belah pihak untuk melakukan penundaan pembayaran hutang.

c. Jangka dan tempo pembayaran hutang jelas.

d. Tidak adanya tambahan bunga atau syarat manfaat lainnya ketika jatuh tempo pembayaran.

e. Akad Moratorium tersebut didasari atas keridhoan antara kedua belah pihak. Artinya kesiapan menanggung resiko atas keterlambatan ditanggung oleh kedua belah pihak.

Adapun kondisi dilarang melakukan moratorium adalah kebalikan dari kondisikondisi di atas.

3. Adapun hukum tambahan dalam moratorium pembayaran hutang maka dalam syariah tidak membolehkan debitur untuk mensyaratkan dalam akad hadiah dan manfaat apapun dari pinjaman. Manfaat dan hadiah yang disyaratkan itu adalah riba yang dilarang dalam pandangan syariah. Adapun tambahan yang bersifat suka rela dan 
tidak dipersyaratkan dalam akad utang piutang maka hal tersebut dibolehkan

Adapun hukum denda dalam penundaan pembayaran hutang. Jika denda tersebut karena murni penundaan dan tidak terkait dengan keuntungan yang pasti bisa diraih dengan penundaan hutang maka hal tersebut dilarang. Namun jika denda tersebut disebabkan kemudharatan akan hilangnya keuntungan yang dipastikan diperoleh jika tidak terjadi keterlambatan hutang ,maka disini ada perbedaan di kalangan ulama antara melarang dan membolehkan.

4. Sanksi hukum bagi seorang yang mampu membayar hutang dan menunda-nundanya adalah haram karena termasuk kezhaliman. Apabila orang yang mampu tersebut menyembunyikan kekayaannya, maka hakim berhak memenjarakannya bahkan memberikan hukuman lain sampai mengeluarkan hartanya. Apabila ia beralasan hartanya hilang, maka alasan tersebut tidak bisa diterima sampai ada bukti yang akurat. Apabila dia tidak ada bukti yang jelas ,maka berhak dipenjara. Adapun tujuan memenjarakan tersebut semata-mata hanya untuk mencari kejelasan harta kekayaannya. Jika ternyata didapati benar-benar tidak ada maka dia wajib dibebaskan. Sedangkan sanksi bagi orang yang tidak bisa membayar hutang sebagai berikut:

\section{a. Sanksi di dunia}

Orang yang tidak mampu membayar hutang maka di dunia dia berhak mendapat sanksi berupa pelarangan pembelanjaan harta (penyitaan) atau harta tersebut dijual dan digunakan untuk melunasi hutanghutangnya.

\section{b. Sanksi di akhirat}

Adapun sanksi bagi orang yang tidak bisa membayar hutang maka dosanya tidak akan di ampuni meskipun ia meninggal dalam keadaan syahid.

\section{DAFTAR PUSTAKA}

Abdullah, Muhammad Ibnu a1 A'robi, Ahkam al Qur'an, Dar a1 Kutub al ilmiyyah, Beirut.

Al-Bukhari, Muhammad bin Ismail, Shahih al Bukhari, Dar Ibn Katsir, Beirut, 1987.

Al Maqdisi, Ibnu Qudamah, Al Mughni, Darul Fikr, Beirut, 1405 H.

al-Nawawy, Muhyiddin ibn Syarf, alMajmû' Syarḥ al-Muhadzdzab, Dâr al-Fikr, Beirut, 1996.

al-Tamratâsyi, Syams al-Dîn, Râd alMuhtâr 'Alâ Dâr al-Mukhtâr, hasyî̀'ah ibn 'Âbidîn. 'Alâ Syarh Syaikh 'Alâ al-Dîn Munhammad ibn 
'Ali al-Hashkafy, Dâr al-Ma'rîfah,

Beirut, 2000.

Ayub, Hasan, Fiqh al Mu 'amalat al Maliyah fi al Islam, Dar a1 Salam, Mesir, 2006.

Ibnu Ahmad ath Thobroni, Sulaiman, Mujam ath Thobroni, Maktabah al Ulum wa al Hikam, Irak.

Ibnu 'Ali Ibnu Muhammad asy Syaukani, Muhammad, Nailul al Author min Ahadits Sayyidu al Ahyar Syarh Muntaqo al Akhbar, Dar Ibnu Haun, Beirut, 2000.

Ibnu Hajjaj, Muslim, Shahih Muslim, Dar Ihya' al Turots al 'Arobi, Beirut.

Ibnu Hambal, Ahmad, Musnad Imam Ahmad, Muasasah a1-Qurtubah.

Ibnu Isa al Tirmidu, Muhammad, al Jami' al Shahih Sunan al Tirmrdzi, Dar Ihya' a1

Ibnu Ismail a1 Bukhori, Muhammad, al Jami ' ash Shahih, Daral Sya'b, Mesir, 1987.

Ibnu Jarir ath Thobari, Muhammad, Jami'ul Bayan 'An Ta 'wil Ayi al Qur 'an, Dar Ibnu Hazm.

Ibnu Katsir, Tafsir alQur 'an al 'Adzim, Dar Toyyibah li Nasyri wa Tauzi,' 1999.

Ibnu Nashir as Sa'di, Abdurrahman, Taisir al Karim al Rahman fi Tafsir
Kalam al Manan, Muasasah al Risalah, Beirut, 1996.

Lukman al Salafi, Muhammad, Tuhfatul Kirom Syarah Bulughul Maram, Dar al Da'i li Nasyri wa Tauzii, Riyadh, 2000.

Muhammad Ibnu al Khotib asy Syarbini, Syamsuddin, Mughni al Muhtaj ila Ma 'rifati Ma 'ani al Alfadz al Minhaj, Dar al Fikr, Beirut, 1998.

Pusat Bahasa, Kamus Besar Bahasa Indonesia, PT Gramedia Pustaka Utama, Jakarta.

Qardhawi, Yusuf, Norma dan Etika Ekonomi Islam, Gema Insani Press, Jakarta,1997.

Sulaiman Ibnu Sholih al Daakhil, al Ta'widh 'an al Adhror al Mutarottabah 'ala al Mumatholah fi al Duyun, http://www.saaid.net.

Syamsuddin al Haq al 'Adzim, Muhammad, Ainul Ma'bud Syarhu Sunan Abu Dawud, Dar al Kutub al Ilmiyyah, Beirut.

Tahir, Muhammad Mansoori, KaidahKaidah keuangan dun Transaksi Bisnis, Ulil Albaab Institute Pasca Sarjana Universitas Ibnu Khaldun, Bogor, 2010. 